Acta Universitatis Lodziensis

www.czasopisma.uni.lodz.pl/foe/

$1(352) 2021$

DOI: https://doi.org/10.18778/0208-6018.352.05

\title{
Joanna Adrianowska
}

Uniwersytet Łódzki, Wydział Ekonomiczno-Socjologiczny, Katedra Metod Statystycznych

Łódź, Polska, joanna.adrianowska@uni.lodz.pl

\section{Miary starości i starzenia się ludności w ujęciu potencjalnym - analiza na przykładzie Polski ${ }^{1}$}

Streszczenie: Artykuł przedstawia propozycje współczynników starzenia się ludności z perspektywy demografii potencjalnej - w ujęciu statycznym i dynamicznym. Prezentuje sposób wyliczania potencjałów życiowych dla populacji oraz dla poszczególnych grup wiekowych, które stanowią punkt wyjścia w demografii potencjalnej. Wartości współczynników starzenia się ludności w kategoriach pojęć demografii potencjalnej zostały obliczone na przykładzie Polski.

Słowa kluczowe: demografia, starzenie się ludności, demografia potencjalna

JEL: J11, J14

1 Praca prezentowana na konferencji MSA 2019 - „Organizacja międzynarodowej konferencji Multivariate Statistical Analysis 2019 (MSA 2019)" - zadanie finansowane w ramach umowy 712/P-DUN/202019 ze środków Ministra Nauki i Szkolnictwa Wyższego przeznaczonych na działalność upowszechniającą naukę. 


\section{Wprowadzenie}

Proces starzenia się ludności jest naturalnym procesem demograficznym, który zarówno w Polsce, jak i w innych krajach przybrał obecnie niespotykane wcześniej natężenie. Zjawisko to generuje wiele wyzwań dla systemów opieki zdrowotnej, socjalnej czy systemów emerytalnych. Widoczne zmiany w zakresie funkcjonowania tych systemów przejawiają się między innymi we wzroście transferów społecznych kierowanych do tej części populacji.

Proces starzenia się ludności wymaga bieżącego monitorowania i analizowania w celu uchwycenia zarówno ogólnego trendu, jak i międzyregionalnych różnic. Do analizy tego procesu wykorzystuje się najczęściej wskaźniki demograficzne konstruowane na podstawie proporcji liczby ludności w określonych grupach wieku. Przykładem może być iloraz liczby osób w wieku poprodukcyjnym do liczby osób w wieku przedprodukcyjnym. Wskaźniki oparte na proporcjach liczby ludności według wieku określać będziemy dalej mianem wskaźników tradycyjnych.

W demografii potencjał życiowy populacji lub, innymi słowy, potencjalne życie populacji jest miarą kapitału demograficznego (Blangiardo, Rimoldi, 2013), od którego zależy przyszłość tej populacji. Potencjał życia, którym dana populacja „dysponuje”, wyznacza się w tym podejściu na podstawie średniego dalszego trwania życia, będącego głównym parametrem tablic trwania życia (oznaczanych jako TTŻ). Dane te stanowią wartości wyjściowe w analizach opartych na demografii potencjalnej. W tym ujęciu przy obliczaniu wartości współczynników demograficznych nie wykorzystuje się tylko proporcji liczebności populacji w określonych grupach wieku, ale także średni czas życia osób w poszczególnych grupach wieku.

Choć pojęcie demografii potencjalnej pojawiło się w latach czterdziestych ubiegłego wieku, to koncepcja ta pozostawała do lat osiemdziesiątych mało znana. Jednak ostatnio podejście to nabiera coraz większego znaczenia i popularności ze względu na łatwy dostęp do baz statystyki publicznej, w tym zwłaszcza do tablic trwania życia, danych na temat struktury populacji według płci, wieku, migracji, a także ze względu na możliwość łatwego korzystania z informatycznych narzędzi obliczeniowych. Szczególnie znanym przykładem zastosowania demografii potencjalnej jest na przykład koncepcja potencjalnych lat utraconego życia (PYLL), wyznaczanych w zależności od uwarunkowań zdrowotnych. Dokładny przegląd badań dotyczących tego zagadnienia znaleźć można w pracy Panusha i Peritza (1996).

Szczególnie interesujące jest jednak ujęcie potencjalne zagadnienia starzenia się populacji, ponieważ zjawisko to jest bezpośrednio związane zarówno ze wzrostem udziału osób starszych w populacji, jak i z wydłużaniem się średniego czasu trwania życia. Podejście potencjalne do tego zagadnienia było przedmiotem zainteresowania wielu autorów, między innymi Friesa (1980), Mantona, Stallarda i Trolleya (1991), Oeppena i Vaupela (2002), Sandersona i Scherbova (2005; 2006), Bongaartsa (2006), Carnesa i Olshansky'ego (2007) oraz Lutza, Sandersona i Scherbova (2008). 
Artykuł ma na celu przedstawienie potencjalnych współczynników starzenia się ludności, opartych na pojęciu potencjału życiowego, będących propozycjami własnymi i zaczerpniętymi z literatury przedmiotu.

W szczególności artykuł prezentuje pojęcie potencjałów dla poszczególnych grup wiekowych, na podstawie których definiowane są miary starzenia, a także zawiera własne propozycje indeksu starości i współczynnika wsparcia, zbudowane przy użyciu tych pojęć. Sposób wyznaczania analizowanych miar wraz z odniesieniem ich wartości do wskaźników tradycyjnych zilustrowany został na przykładzie Polski dla roku 2017.

Struktura artykułu jest następująca. W sekcji drugiej omówiono dwa podstawowe pojęcia demografii potencjalnej - potencjał życiowy populacji i jednostki. W sekcjach trzeciej oraz czwartej przedstawione zostały potencjalne miary starzenia demograficznego, odpowiednio w ujęciu statycznym i dynamicznym, oparte na propozycjach własnych i zaczerpniętych z literatury przedmiotu. Wartości tych miar zostały dodatkowo porównane z wartościami ich odpowiedników tradycyjnych na przykładzie Polski. Ponadto w aneksie zamieszczone zostały dane źródłowe, na których oparto obliczenia. Sekcja piąta zawiera wnioski podsumowujące.

\section{Podstawowe pojęcia demografii potencjalnej}

\subsection{Tablice trwania życia w demografii potencjalnej}

Przy wyznaczaniu współczynników demograficznych przyjmuje się zwykle, że badanymi jednostkami są osoby lub zdarzenia. Przykładowo: w ujęciu klasycznym wartość indeksu starości demograficznej oblicza się jako relację pomiędzy liczbą osób w wieku poprodukcyjnym a liczbą osób wieku przedprodukcyjnym. Współczynnik ten przypisuje jednak takie samo znaczenie subpopulacji osób starszych i osób młodych. Jednak z perspektywy umieralności i starzenia, określone subpopulacje kryją w sobie inny potencjał życiowy i w tym sensie mają inną wagę. Ludność różni się pod tym względem na przykład między grupami wieku. Również dla potrzeb ekonomicznych różne struktury demograficzne ludności nie mają takiej samej wagi, ponieważ różnią się ze względu na płeć, wiek i inne cechy społeczno-ekonomiczne.

Zróżnicowanie ze względu na wagi przypisane do jednostek uwzględnia demografia potencjalna. Ta dziedzina powstała w wyniku próby przezwyciężenia pewnych trudności interpretacyjnych powstających w obszarze demografii tradycyjnej.

Podstawową wartością demografii potencjalnej jest potencjał życiowy jednostki, definiowany za pomocą oczekiwanej liczby lat, jaką ma ona do przeżycia według obowiązujących tablic trwania życia (Murkowski, 2013). 
Demografia potencjalna różnicuje jednostki, przypisując im odpowiednie wagi, wyrażone za pomocą średniego dalszego trwania życia. Ważne jest tutaj określenie oczekiwanej liczby lat, które dana jednostka może przeżyć, będąc obecnie $\mathrm{w}$ wieku $x$ lat, i określonej liczby lat po osiągnięciu wieku $x+y$. W demografii w ujęciu potencjalnym nie liczy się zatem ludzi czy zdarzeń, ale czas - rozumiany jako potencjał życiowy poszczególnych jednostek. Potencjał ten ustala się na podstawie tablic trwania życia. $\mathrm{Z}$ pełnym opisem tablic trwania życia można się zapoznać w książce Kędelskiego i Paradysza (2006).

Tablice trwania życia podają między innymi przeciętną długość dalszego trwania życia osoby w wieku $x$ ukończonych lat, która oznaczana jest symbolem $e_{x}$. Parametr ten wyraża średnią liczbę lat, jaką ma do przeżycia - w danych warunkach umieralności - osoba w wieku $x$ ukończonych lat, przy założeniu, że warunki te będą utrzymywały się przez dostatecznie długi czas.

Zobrazowanie tego parametru przedstawia Wykres 1 . Widzimy, że kobiety cechują się dłuższym niż mężczyźni średnim dalszym trwaniem życia. Przykładowo: dla kobiet w wieku 50 lat parametr $e_{x}$ wynosi około 33 lata, natomiast dla mężczyzn w tym samym wieku około 26 lat. Różnica w oczekiwanej długości dalszego życia zmniejsza się między mężczyznami i kobietami wraz ze wzrostem wieku.

Zauważymy także, że szanse dożycia określonej liczby lat rosną wraz z wiekiem. Na przykład, 75-letni mężczyzna może dożyć średnio wieku $75+12,75=87,75$ lat, a noworodek - wieku 73 lat. Oczekiwane dalsze trwanie życia mężczyzn w wieku 75 lat wynosi bowiem 12,75 lat, natomiast średnie dalsze trwanie życia chłopców urodzonych w 2017 roku wynosi 73 lata (Wykres 1).
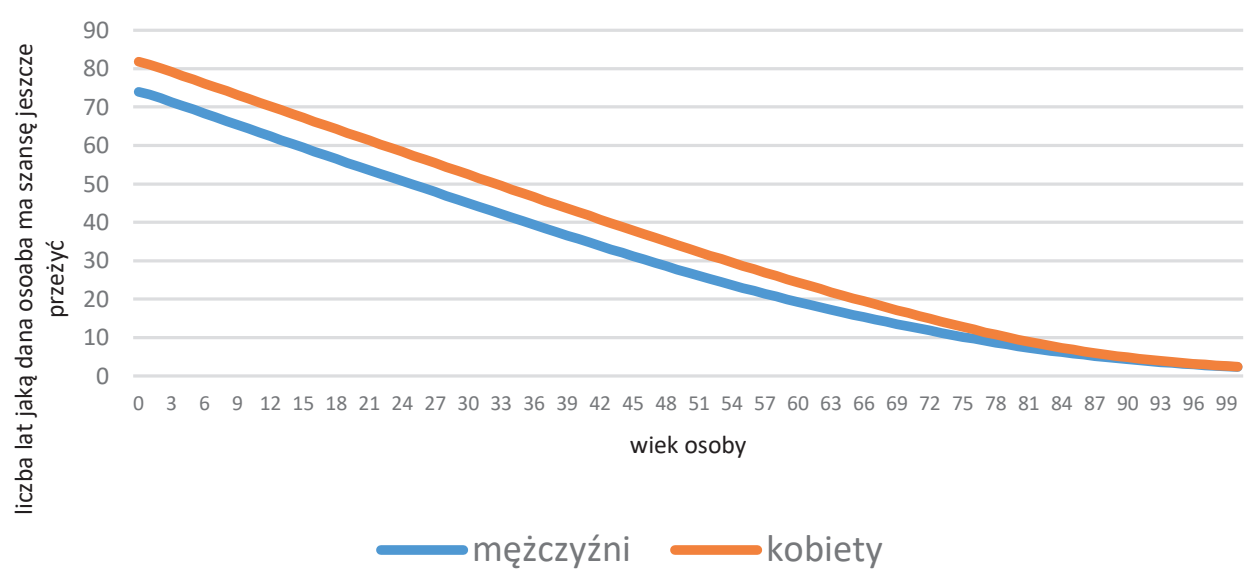

Wykres 1. Oczekiwana liczba lat, jaką ma szanse przeżyć osoba mająca ustalony wiek, na podstawie tablic trwania życia na rok 2017

Źródło: opracowanie własne na podstawie danych Eurostatu 


\subsection{Miary potencjału życiowego jednostki i populacji}

W demografii potencjalnej głównymi miarami konstruowanymi na podstawie parametru $e_{x}$ są: potencjał życiowy jednostki oraz całkowity potencjał życiowy populacji. Pierwszy z nich oblicza się jako wielkość średnią z przeciętnego dalszego trwania życia osób będących w wieku $x$ oraz w wieku $x+1$ lat. Potencjał życiowy $V(x)$ jednostki obliczamy ze wzoru:

$$
V(x)=\frac{e_{x}+e_{x+1}}{2} .
$$

Przykładowo: potencjał życiowy mężczyzny w wieku 25 lat, wyznaczony na podstawie danych $\mathrm{z}$ tablicy trwania życia dla mężczyzn zamieszczonej w załączniku 2, wynosi:

$$
V(25)=\frac{e_{25}+e_{26}}{2}=\frac{50,72+48,82}{2}=49,30 \text { lat } .
$$

Tabela 1 przedstawia przykładowe wartości potencjału życiowego osób w określonym wieku, obliczone na podstawie załącznika 2.

Tabela 1. Potencjał życiowy $V(x)$ osób w wieku $x$

\begin{tabular}{|c|c|c|}
\hline $\boldsymbol{V}(\boldsymbol{x})$ & Mężczyzna & Kobieta \\
\hline$V(5)$ & 68,85 & 76,66 \\
\hline$V(25)$ & 49,30 & 56,87 \\
\hline$V(60)$ & 18,89 & 23,92 \\
\hline$V(85)$ & 5,66 & 6,61 \\
\hline
\end{tabular}

Źródło: opracowanie własne na podstawie TTŻ dla Polski na rok 2017 (załącznik 2)

Na podstawie danych z Tabeli 1 zauważyć można, że wartości potencjałów życiowych, podobnie jak wartości przeciętnego dalszego trwania życia, są wyższe dla kobiet niż dla mężczyzn w różnym wieku, choć różnice te maleją wraz ze wzrostem wieku.

Poza $V(x)$ można dodatkowo wyznaczyć potencjał życiowy osób w danym wieku w okresie ich życia od $n$ do $N$ lat, czyli określić przeciętną liczbę lat życia $x$-latków w przedziale wieku $[n, N]$ lat, przy założeniu, że $x \leq n<N$. Liczbę tę wyznaczamy z następującego wzoru:

$$
V(x ; n, N)=\frac{l_{n} e_{n}-l_{N} e_{N}}{\frac{1}{2}\left(l_{x}+l_{x+1}\right)},
$$

gdzie:

$x$ - ustalony wiek,

$n, N$-odpowiednio dolny i górny wiek rozważanego okresu, 
$l_{x}$ - liczba osób dożywających wieku $x$ ukończonych lat, $e_{n}, e_{N}$-wartość przeciętnego dalszego trwania życia dla osób w wieku odpowiednio $n$ i $N$ ukończonych lat.

Na przykład: dla chłopców w wieku 5 ukończonych lat potencjał życiowy w okresie ich życia od 65 do 100 lat, obliczony na podstawie wzoru (2), ma postać:

$$
V(5 ; 65,100)=\frac{l_{65} e_{65}-l_{100} e_{100}}{\frac{1}{2}\left(l_{5}+l_{6}\right)} .
$$

Na podstawie danych z załącznika 2 otrzymujemy:

$$
V(5 ; 65,100)=\frac{75837 \cdot 15,93-941 \cdot 2,33}{\frac{1}{2}(99482+99473)}=\frac{1205890,88}{99477,50}=12,12 \text { lat. }
$$

Wielkość tę możemy interpretować jako oczekiwany czas życia w przedziale wieku $[65,100]$ lat przypadający na osobę (chłopca), która w roku 2017 ukończyła 5 lat. Zauważmy, że wartość ta jest mniejsza niż szerokość analizowanego przedziału wieku, wskaźnik $V(5 ; 65,100)$ obliczony jest tu bowiem z uwzględnieniem faktu, że znaczna część 5-latków nie dożyje dolnej granicy przedziału wieku $[65,100]$ lat, a wśród pozostałych wielu nie ukończy wieku 100 lat.

Inne przykładowe wartości wskaźnika $V(x ; n, N)$ są przedstawione w Tabeli 2.

Tabela 2. Potencjał życiowy $V(x ; n, N)$ osób w wieku $x$, obliczony na podstawie tablic trwania życia dla Polski z 2017 roku

\begin{tabular}{|c|c|c|}
\hline $\boldsymbol{V}(\boldsymbol{x} ; \boldsymbol{n}, \boldsymbol{N})$ & Mężczyźni & Kobiety \\
\hline$V(5 ; 65,100)$ & 12,12 & 18,15 \\
\hline$V(25 ; 50,65)$ & 13,05 & 14,25 \\
\hline$V(60 ; 85,100)$ & 1,96 & 3,49 \\
\hline
\end{tabular}

Źródło: opracowanie własne na podstawie TTŻ na rok 2017 (załącznik 2)

Drugim ważnym pojęciem wykorzystywanym w demografii potencjalnej jest całkowity potencjał życiowy (Vielrose, 1958: 42), który oznaczać będziemy symbolem $P C$. Określa on oczekiwaną liczbę lat, jaką ma do przeżycia badana populacja łącznie. Oblicza się go ze wzoru:

$$
P C=V(0, \omega ; 0, \omega)=\sum_{x=0}^{\omega-1} P_{x} \frac{e_{x}+e_{x+1}}{2},
$$

gdzie:

$\omega$ - górna granica wieku w tablicy trwania życia, w którym liczba dożywających osób jest równa zeru,

$P x$ - średnia liczba ludności dla danego rocznika wieku, $e_{x}-$ przeciętne dalsze trwanie życia osób w wieku $x$ ukończonych lat. 
Dla ludności Polski całkowity potencjał życiowy obliczony na podstawie wzoru (3) oraz danych z załącznika 2, przyjmując $\omega=100$ lat, wynosi:

1) dla mężczyzn $P C_{M}=V(0, \omega ; 0, \omega)=692646763$ lat,

2) dla kobiet $P C_{K}=V(0, \omega ; 0, \omega)=804976314$ lat .

$\mathrm{Z}$ całkowitego potencjału życiowego wyodrębniamy także potencjały częściowe, czyli oczekiwaną liczbę pozostałych lat życia wśród osób będących w ustalonej grupie wieku (Murkowski, 2018a). Potencjał osób będących w wieku od $m$ do $M$ lat w relacji do ich dalszego okresu życia oznaczać będziemy symbolem $V_{1}(m, M$; $m, \omega)$ i obliczać ze wzoru:

$$
V_{1}(m, M ; m, \omega)=\sum_{x=m}^{M-1} P_{x} \frac{e_{x}+e_{x+1}}{2} .
$$

Przykładowo: dla subpopulacji mężczyzn w grupie wieku od $m=65$ lat do $M=100$ lat potencjał częściowy wynosi:

$$
V_{1}(65,100 ; 65,)=\sum_{x=65}^{99} P_{x} \frac{e_{x}+e_{x+1}}{2}=27628200 \text { lat. }
$$

Tabela 3 zawiera wartości częściowych potencjałów życiowych osób w określonych grupach wieku, obliczone na podstawie wzoru (4) oraz danych z załącznika 2, w tym:

1) $V_{1}(65,100 ; 65, \omega)$ - oczekiwaną liczbę pozostałych lat życia wśród osób w wie$\mathrm{ku} 65-100$ lat,

2) $\quad V_{1}(85,100 ; 85, \omega)$ - oczekiwaną liczbę pozostałych lat życia wśród osób w wie$\mathrm{ku} 85-100$ lat,

3) $\quad V_{1}(0,18 ; 0, \omega)$ - oczekiwaną liczbę pozostałych lat życia wśród osób w wieku $0-18$ lat,

4) $V_{1}(18,65 ; 18, \omega)$ - oczekiwaną liczbę pozostałych lat życia wśród osób w wieku $18-65$,

5) $\quad V_{1}(0,15 ; 0, \omega)$ - oczekiwaną liczbę pozostałych lat życia wśród osób w wieku $0-15$ lat,

6) $\quad V(15,65 ; 15, \omega)$ - oczekiwaną liczbę pozostałych lat życia wśród osób w wieku 15-65 lat.

Na podstawie danych z Tabeli 3 możemy wnioskować, że wartość potencjałów życia w subpopulacji osób w wieku 65-100 lat w Polsce znacząco różni się w przypadku kobiet i mężczyzn. Potencjał częściowy dla kobiet w tej grupie wieku był w roku 2017 prawie dwukrotnie większy niż dla mężczyzn. Dla kobiet wielkość ta wynosiła łącznie 49448385 lat, a dla mężczyzn 27628200 lat. Również dla osób w wieku 85-100 lat potencjał częściowy był niemal trzykrotnie większy w przypadku subpopulacji kobiet w porównaniu z mężczyznami. $\mathrm{Z}$ kolei dla osób w wieku do 15 lat wartości potencjałów w podziale na płeć były do siebie zbliżone. 
Tabela 3. Potencjał życiowy osób w wieku od $m$ do M lat w relacji do ich dalszego czasu życia

\begin{tabular}{|c|c|c|}
\hline Wskaźniki & Mężczyźni & Kobiety \\
\hline$P C$ & 692646763 & 804976314 \\
\hline$V_{1}(0,18 ; 0, \omega)$ & 229974285 & 244193547 \\
\hline$V_{1}(18,65 ; 18, \omega)$ & 435044278 & 511334382 \\
\hline$V_{1}(65,100 ; 65, \omega)$ & 27628200 & 49448385 \\
\hline$V_{1}(85,100 ; 85, \omega)$ & 1257989 & 3560066 \\
\hline$V_{1}(0,15 ; 0, \omega)$ & 196906033 & 208517952 \\
\hline$V_{1}(15,65 ; 15, \omega)$ & 468112530 & 547009977 \\
\hline
\end{tabular}

Źródło: opracowanie własne na podstawie TTŻ dla Polski z roku 2017 (załącznik 2)

Zauważmy ponadto, że następujące sumy potencjałów częściowych równe są potencjałowi całkowitemu $P C$ :

$$
\begin{aligned}
& V_{1}(0,18 ; 0, \omega)+V_{1}(18,65 ; 18, \omega)+V_{1}(65,100 ; 65, \omega), \\
& V_{1}(0,15 ; 0, \omega)+V_{1}(15,65 ; 15, \omega)+V_{1}(65,100 ; 65, \omega) .
\end{aligned}
$$

$\mathrm{Z}$ całkowitego potencjału życiowego $P C$ można wydzielić dodatkowo liczbę lat do przeżycia w ustalonym przedziale wieku, niezależnie od faktu, czy w danym momencie już osiągnięty został wiek uznawany za początek tego okresu (Vielrose, 1958: 40; Murkowski, 2018a).

W tym ujęciu oblicza się potencjał życiowy osób w wieku od $m$ do $M$ lat przypadający na okres życia od $n$ do $N$ lat, przy warunku $m<M \leq n<N$. Potencjał ten oznaczać będziemy symbolem $V_{2}(m, M ; n, N)$ i obliczać ze wzoru:

$$
V_{2}(m, M ; n, N)=\left(l_{n} e_{n}-l_{N} e_{N}\right) \cdot \sum_{x=m}^{M-1} \frac{P_{x}}{\frac{1}{2}\left(l_{x}+l_{x+1}\right)}
$$

Tabela 4 zawiera przykładowe wartości wskaźnika $V_{2}(m, M ; n, N)$, obliczone na podstawie wzoru (5), w tym:

1) $V_{2}(0,15 ; 65, \omega)$ - oczekiwaną liczbę lat życia osób w wieku do 15 lat, gdy będą w wieku powyżej 65 lat,

2) $\quad V_{2}(15,65 ; 65, \omega)$ - oczekiwaną liczbę lat życia osób w wieku 15-65 lat, gdy będą w wieku powyżej 65 lat,

3) $V_{2}(0,15 ; 85, \omega)$ - oczekiwaną liczbę lat życia osób w wieku do 15 lat, gdy będą w wieku powyżej 85 lat,

4) $V_{2}(15,65 ; 85, \omega)$ - oczekiwaną liczbę lat życia osób w wieku $15-65$ lat, gdy będą w wieku powyżej 85 lat, 
5) $\quad V_{2}(65,85 ; 85, \omega)$ - oczekiwaną liczbę lat życia osób w wieku $65-85$ lat, gdy będą w wieku powyżej 85 lat,

6) $V_{2}(0,15 ; 15, \omega)$ - oczekiwaną liczbę lat życia osób w wieku do 15 lat, gdy będą w wieku 15-65 lat.

Tabela 4. Potencjał życiowy osób w wieku od $m$ do M lat przypadający na okres życia od $n$ do $M$ lat

\begin{tabular}{|c|r|c|}
\hline Wskaźniki & Mężczyźni & Kobiety \\
\hline$V_{2}(0,15 ; 65, \omega)$ & 35665095 & 50633425 \\
\hline$V_{2}(15,65 ; 65, \omega)$ & 167220809 & 246739507 \\
\hline$V_{2}(0,15 ; 85, \omega)$ & 4346513 & 9110074 \\
\hline$V_{2}(15,65 ; 85, \omega)$ & 20379237 & 44393899 \\
\hline$V_{2}(65,85 ; 85, \omega)$ & 6236062 & 14168505 \\
\hline$V_{2}(0,15 ; 15,65)$ & 44129104 & 41860238 \\
\hline
\end{tabular}

Źródło: opracowanie własne na podstawie TTŻ dla Polski z roku 2017 (załącznik 2)

Wartości potencjałów zawarte w Tabeli 4 różnią się w podziale na płeć. Subpopulację kobiet cechuje wyższa w porównaniu do subpopulacji mężczyzn liczba lat do przeżycia zarówno w wieku 65+, jak i w okresie starości, tj. w wieku 85+. Taka relacja potencjałów miała miejsce we wszystkich grupach wieku, tj. $0-15$, 15-65 i 65-85 lat.

Rozważmy teraz potencjał życiowy subpopulacji w wieku $[m, M]$ lat, przypadający na okres życia $[m, N]$ lat, przy warunku $m<M \leq N$. Liczbę tę oznaczać będziemy symbolem $V_{3}(m, M ; m, N)$ i obliczać ze wzoru:

$$
V_{3}(m, M ; m, N)=\sum_{x=m}^{M-1} P_{x}\left(\frac{e_{x}+e_{x+1}}{2}-\frac{l_{N} e_{N}}{\frac{1}{2}\left(l_{x}+l_{x+1}\right)}\right) .
$$

Warto zauważyć, że $V_{3}(m, M ; m, N)$ można wyrazić jako różnicę potencjałów częściowych $V_{1}(m, M ; m, \omega)$ i $V_{2}(m, M ; N, \omega)$, czyli:

$$
V_{3}(m, M ; m, N)=V_{1}(m, M ; m, \omega)-V_{2}(m, M ; N, \omega) .
$$


Poniżej rozważymy kilka przykładów ilustrujących wykorzystanie formuł (4)-(7).

Potencjał życiowy populacji w przedziale wieku od 0 do 15 lat wyraża się wzorem:

$$
V(0, \omega ; 0,15)=V_{3}(0,15 ; 0,15)=\sum_{x=0}^{14} P_{x}\left(\frac{e_{x}+e_{x+1}}{2}-\frac{l_{15} e_{15}}{\frac{1}{2}\left(l_{x}+l_{x+1}\right)}\right) .
$$

Z kolei potencjał życiowy populacji w okresie życia od 15 do 65 lat obliczymy jako sumę potencjałów $V_{2}(0,15 ; 15,65), V_{3}(15,65 ; 15,65)$, czyli:

$$
V(0, \omega ; 15,65)=V_{2}(0,15 ; 15,65)+V_{3}(15,65 ; 15,65),
$$

gdzie $V_{2}$ to wartości wyliczone na podstawie wzoru (4), a $V_{3}$ ze wzoru (6).

Możemy wyznaczać także oczekiwaną liczbę lat, jaką ma do przeżycia w przedziale wieku od $n$ do $N$ lat populacja będąca w przedziale wieku od $m$ do $M$ lat, gdy $m \leq n<M \leq N$.

Na przykład: potencjał życiowy osób w wieku od 50 do 65 lat w przedziale wieku od 50 do 85 lat jest równy $V_{3}(50,65 ; 50,85)$, a tym samym potencjał życiowy osób będących w wieku od 15 do 65 lat obliczony dla przedziału wieku od 50 do 85 lat jest sumą potencjałów postaci:

$$
V(15,65 ; 50,85)=V_{2}(15,50 ; 50,85)+V_{3}(50,65 ; 50,85),
$$

gdzie $V_{2}$ to wartość wyliczona na podstawie wzoru (5), a $V_{3}$ na podstawie wzoru (6).

Obliczymy teraz oczekiwaną łączną liczbę lat życia populacji po osiągnięciu wieku 65 lat, niezależnie, czy w rozważanym czasie poszczególne osoby już osiągnęły ten wiek. Tym razem skorzystamy z sumy potencjałów częściowych $V_{1}, V_{2}$ postaci:

$$
V(0, \omega ; 65, \omega)=V_{1}(65, \omega ; 65, \omega)+V_{2}(0,65 ; 65, \omega),
$$

gdzie $V_{1}$ to wartość wyliczona na podstawie wzoru (4), natomiast $V_{2}$ na podstawie wzoru (5).

Podobnie potencjał życia ludności w wieku 85 i więcej lat oznacza oczekiwaną łączną liczbę lat, jaką dana zbiorowość jednostek ma do przeżycia w okresie starości, czyli:

$$
V(0, \omega ; 85, \omega)=V_{1}(85, \omega ; 85, \omega)+V_{2}(0,85 ; 85, \omega),
$$

gdzie $V_{1}$ to wartość wyliczona na podstawie wzoru (4) i $V_{2}$ na podstawie wzoru (5). 
Inne przykładowe obliczenia oparte na danych z tablic trwania życia dla Polski z roku 2017 zawiera Tabela 5.

Na podstawie zawartych w tej tabeli danych stwierdzamy, że ludność Polski w wieku 65+ miała w roku 2017 do przeżycia łącznie $575 \mathrm{mln}$ lat, co stanowiło $38,4 \%$ całkowitego potencjału życia populacji.

Zgodnie z podaną w artykule Murkowskiego (2018b) prognozą na lata 2020, 2030, 2040 i 2050 potencjał całkowity ludności będzie malał, natomiast potencjał życiowy ludności w wieku 65+ będzie wzrastał i w roku 2050 będzie stanowił $47,6 \%$ całego potencjału ludności. Potencjał życiowy w okresie wieku sędziwego $80+$ w roku 2017 w Polsce stanowił 13,5\% całkowitego potencjału populacji i wzrośnie do około $20,7 \%$ w roku 2050. Projekcję tych przemian ilustruje także Wykres 2.

Tabela 5. Wartości potencjałów w ujęciu dynamicznym dla populacji Polski w roku 2017 oraz prognozy do roku 2050

\begin{tabular}{|l|c|c|c|c|c|c|}
\hline \multicolumn{1}{|c|}{ Wyszczególnienie } & $\mathbf{2 0 1 4}$ & $\mathbf{2 0 1 7}$ & $\mathbf{2 0 2 0}$ & $\mathbf{2 0 3 0}$ & $\mathbf{2 0 4 0}$ & $\mathbf{2 0 5 0}$ \\
\hline $\begin{array}{l}\text { Całkowity potencjał życiowy (mln) } \\
P C\end{array}$ & 1518 & 1498 & 1504 & 1443 & 1381 & 1344 \\
\hline $\begin{array}{l}\text { Liczba lat życia (w mln) ludności } \\
\text { w okresie poniżej 15 lat } \\
V(0, \omega ; 0,15)\end{array}$ & 43 & 43 & 43 & 36 & 34 & 34 \\
\hline $\begin{array}{l}\text { Liczba lat życia (w mln) ludności } \\
\text { w okresie 65+ } \\
V_{3}(0, \omega ; 65, \omega)\end{array}$ & 575 & 575 & 592 & 617 & 631 & 639 \\
\hline $\begin{array}{l}\text { Liczba lat życia (w mln) } \\
\text { w okresie } 80+ \\
V_{3}(0, \omega ; 80, \omega)\end{array}$ & 197 & 203 & 204 & 235 & 258 & 277 \\
\hline $\begin{array}{l}\text { Liczba lat życia (w proc.) ludności } \\
\text { w okresie 65+ }\end{array}$ & 37,9 & 38,4 & 39,4 & 42,8 & 45,7 & 47,6 \\
\hline $\begin{array}{l}\text { Liczba lat życia (w proc.) ludności } \\
\text { w okresie } 80+\end{array}$ & 13,0 & 13,5 & 13,5 & 16,3 & 18,7 & 20,7 \\
\hline
\end{tabular}

Źródło: opracowanie własne na podstawie TTŻ na rok 2017 (załącznik 2) oraz publikacji Murkowski, 2018b 


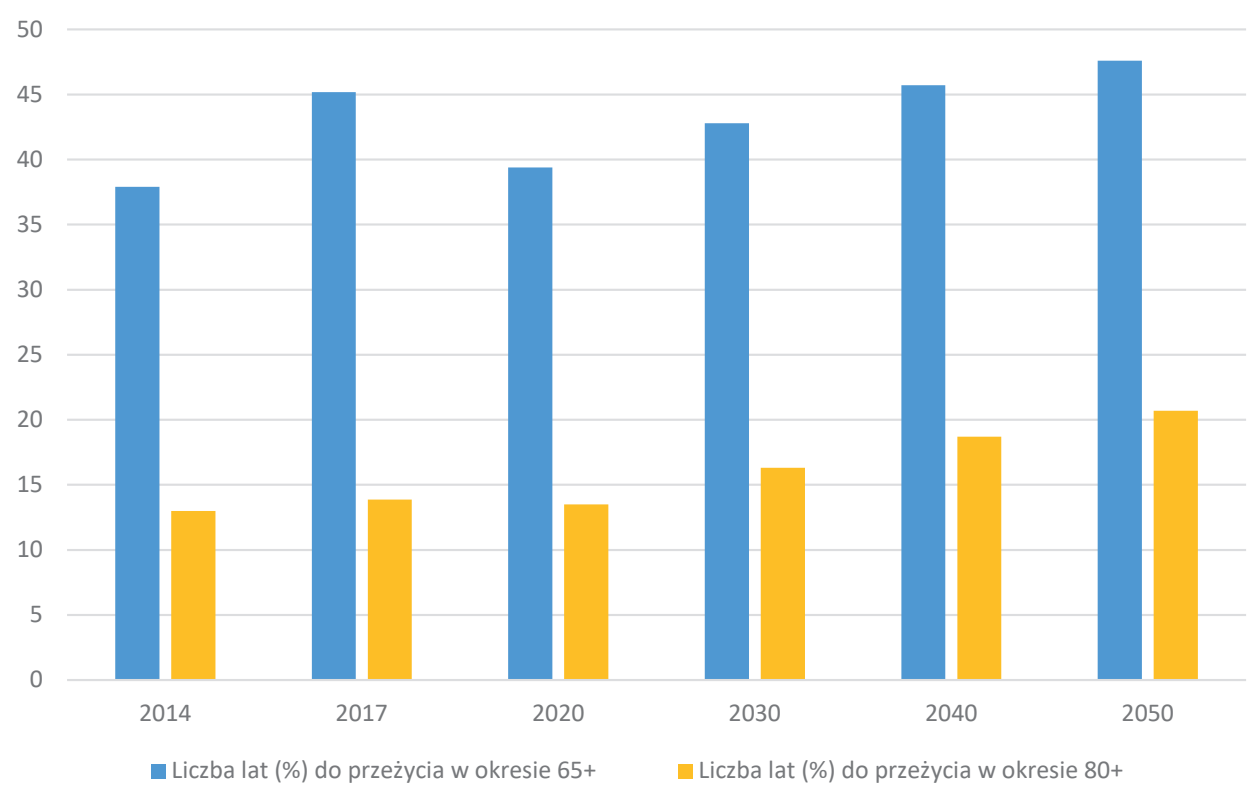

Wykres 2. Udziały potencjału życiowego ludności w wieku 65+ i 80+ w potencjale całkowitym w latach 2014 i 2017 oraz prognozy na lata 2020, 2030, 2040, 2050 Źródło: opracowanie własne na podstawie TTŻ na rok 2017 (załącznik 2)

\section{Starzenie się ludności z perspektywy demografii potencjalnej (ujęcie statyczne)}

W demografii potencjalnej proces starzenia analizuje się na podstawie całkowitego potencjału życiowego i potencjałów częściowych.

Potencjalne współczynniki starzenia oblicza się przez analogię do współczynników tradycyjnych, zastępując liczbę ludności w liczniku i/lub mianowniku danego wskaźnika całkowitym lub częściowym potencjałem życiowym, czyli liczbą lat do przeżycia danej grupy ludności uwzględnionej w definicji współczynnika.

Potencjalny współczynnik starości demograficznej $W_{65+}^{s}$ jest ilorazem potencjalnej liczby lat do przeżycia osób w wieku $65+$ do całkowitego potencjału populacji:

$$
W_{65+}^{s}=\frac{V(65, \omega ; 65, \omega)}{P C} \cdot 100 .
$$

Iloraz ten określa, jaki odsetek całkowitego potencjału życiowego populacji stanowi potencjał życiowy osób będących w wieku $65+$. 
Potencjalny współczynnik zaawansowanej starości to iloraz potencjalnej liczby lat do przeżycia osób w wieku $85+$ do całkowitego potencjału populacji:

$$
W_{85+}^{s}=\frac{V(85, \omega ; 85, \omega)}{P C} \cdot 100 .
$$

Potencjalny współczynnik podwójnego starzenia to iloraz potencjalnej liczby lat do przeżycia osób w wieku 85+ do potencjału życiowego osób w wieku 65+:

$$
W_{85+/ 65+}^{s}=\frac{V(85, \omega ; 85, \omega)}{V(65, \omega ; 65, \omega)} \cdot 100 .
$$

Potencjalny indeks starości demograficznej to wartość określająca relację pomiędzy potencjalną liczbą lat do przeżycia przez osoby w wieku $65+$ do potencjalnej liczby lat do przeżycia przez osoby młode, tj. w wieku do 15 lat, w pozostałym okresie ich życia:

$$
W_{65+10-15}^{s}=\frac{V(65, \omega ; 65, \omega)}{V(0,15 ; 0, \omega)} \cdot 100 .
$$

Indeks ten określa, jakie są proporcje pomiędzy potencjałem życiowym osób młodych i osób starszych.

Współczynnik potencjalnego wsparcia to iloraz potencjału życiowego osób w wieku 15-65 lat do potencjału życiowego osób w wieku 65+:

$$
W_{15-65 / 65+}^{s}=\frac{V(15,65 ; 15, \omega)}{V(65, \omega ; 65, \omega)} \cdot 100 .
$$

Wartości wymienionych współczynników starzenia się ludności Polski, obliczone na podstawie danych z załącznika 2 (w podziale na płeć oraz łącznie), przedstawia Tabela 6. Ostatnia kolumna tabeli zawiera także wartości analogicznych współczynników demograficznych w ujęciu demografii tradycyjnej.

Analizując wartości potencjalnych współczynników demograficznych, rozważmy bliżej dwa z nich, zawarte w Tabeli 6 .

Potencjalny współczynnik starości demograficznej bez podziału na płeć wynosił w roku 2017 około 5,14\%. Wartość ta wskazuje, jaki procentowy udział w całym potencjale życia osób w wieku 0- $\omega$ lat stanowi potencjał życiowy osób w wieku 65+. Jednocześnie w ujęciu tradycyjnym współczynnik ten był równy $16,5 \%$, co oznacza, że $16,5 \%$ całej populacji stanowiła ludność w wieku $65+$.

Potencjalny współczynnik starości demograficznej w subpopulacji mężczyzn wynosił w roku 2017 około 12,6\% w ujęciu tradycyjnym (załącznik 1), a w ujęciu 
potencjalnym 3,99\% (Tabela 6). Tak więc mężczyźni w wieku 65+, mimo że stanowili $12,6 \%$ ogółu mężczyzn, z perspektywy ich udziału w potencjale życiowym tej subpopulacji stanowili zaledwie około 4\%. Kobiety w wieku 65+ w 2017 roku stanowiły ponad $20 \%$ populacji, a jednocześnie ich potencjał życia wynosił $6,14 \%$ potencjału całkowitego populacji, był zatem o ponad 2 p.p. większy niż w przypadku mężczyzn w tej grupie wieku.

Tabela 6. Wartości współczynników demograficznych w ujęciu potencjalnym statycznym, obliczone dla Polski (2017 rok)

\begin{tabular}{|l|r|r|r|c|}
\hline \multirow{2}{*}{$\begin{array}{c}\text { Współczynniki potencjalne - ujęcie } \\
\text { statyczne }\end{array}$} & \multicolumn{4}{|c|}{ Wartość współczynnika } \\
\cline { 2 - 5 } & Mężczyźni & Kobiety & Ogółem & $\begin{array}{c}\text { Wartość } \\
\text { współczynnika } \\
\text { tradycyjnego }\end{array}$ \\
\hline Starości demograficznej & 3,99 & 6,14 & 5,14 & 16,5 \\
\hline Zaawansowanej starości & 0,18 & 0,44 & 0,32 & 1,95 \\
\hline Podwójnego starzenia & 4,55 & 7,19 & 9,50 & 11,78 \\
\hline Indeks starości demograficznej & 14,03 & 23,71 & 12,50 & 109,5 \\
\hline Współczynnik potencjalnego wsparcia & 1694,32 & 1106,22 & 2001,96 & \multicolumn{1}{c|}{413,09} \\
\hline
\end{tabular}

Źródło: opracowanie własne na podstawie TTŻ na rok 2017 (załącznik 2)

W przypadku współczynnika zaawansowanej starości w ujęciu potencjalnym współczynnik ten dla ludności Polski w roku 2017 wynosił 0,32\% (Tabela 6). Jest to udział procentowy potencjału osób w wieku $85+$ w całkowitym potencjale życiowym populacji w tym roku. W ujęciu tradycyjnym współczynnik ten wynosił $1,95 \%$ dla roku 2017, co oznacza, że niemal $2 \%$ całej populacji stanowiły osoby w wieku 85 i więcej lat. W przypadku podziału na płeć wartość w ujęciu tradycyjnym dla mężczyzn wynosiła 1,11\% (załącznik 1), a w ujęciu potencjalnym $0,18 \%$ (Tabela 6). W przypadku kobiet współczynnik zaawansowanej starości wynosił 2,73\% (załącznik 1), a w ujęciu potencjalnym $0,44 \%$ (Tabela 6).

Zauważmy, że obydwa analizowane tu współczynniki - starości demograficznej i zaawansowanej starości - w ujęciu potencjalnym osiągają znacznie niższe wartości niż analogiczne współczynniki w ujęciu tradycyjnym. Wynika to z faktu, że średni czas życia osób zaliczanych do tzw. starszej subpopulacji jest znacznie krótszy od średniego czasu życia pozostałych członków populacji.

\section{Starzenie się ludności z perspektywy demografii potencjalnej (ujęcie dynamiczne)}

W demografii potencjalnej w ujęciu dynamicznym, podobnie jak w ujęciu statycznym, definiujemy różne współczynniki starzenia się ludności. Niektóre z nich wymienione zostały poniżej. 
Współczynnik starości demograficznej określa, jaki odsetek całkowitego potencjału życiowego populacji stanowią lata do przeżycia w okresie starości i jest określony wzorem:

$$
W_{65+}^{d}=\frac{V(0, \omega ; 65, \omega)}{P C} \cdot 100 .
$$

Współczynnik zaawansowanej starości określa, jaki odsetek całkowitego potencjału życiowego populacji stanowią lata do przeżycia w okresie sędziwym i jest określony wzorem:

$$
W_{85+}^{d}=\frac{V(0, \omega ; 85, \omega)}{P C} \cdot 100 .
$$

Współczynnik podwójnego starzenia określa, jaki odsetek lat do przeżycia w okresie starości stanowią lata do przeżycia w okresie sędziwym i jest określony wzorem:

$$
W_{85+/ 65+}^{d}=\frac{V(0, \omega ; 85, \omega)}{V(0, \omega ; 65, \omega)} \cdot 100 .
$$

Indeks starości demograficznej określa, ile razy więcej badana populacja ma do przeżycia w okresie starości niż w okresie młodości i jest określony wzorem:

$$
W_{65+/ 0-15}^{d}=\frac{V(0, \omega ; 65, \omega)}{V(0, \omega ; 0,15)} \cdot 100 .
$$

Współczynnik potencjalnego wsparcia to stosunek potencjału życiowego na lata 15-65 całej populacji do potencjału życiowego w okresie młodości:

$$
W_{15-65 / 65+}^{d}=\frac{V(0, \omega ; 15,65)}{V(0, \omega ; 0,15)} \cdot 100 .
$$

Wartości wymienionych potencjalnych współczynników demograficznych dla populacji Polski w roku 2017 zawiera Tabela 7.

Analizując wybrane współczynniki demograficzne w ujęciu dynamicznym, rozważmy w pierwszej kolejności potencjalny współczynnik starości demograficznej bez podziału na płeć, który w przypadku Polski w roku 2017 wynosił 38,17\%, co interpretujemy jako udział procentowy w potencjale całkowitym, jaki stanowił potencjał życia osób, które już osiągnęły wiek $65+$ oraz osób, które osiągną ten wiek w przyszłości. W podziale na płeć wartość dla mężczyzn stanowiła $33,28 \%$ i była o 10 p.p. niższa niż analogiczny wskaźnik dla kobiet, równy 43,08\% (Tabela 7). 
Tabela 7. Wartości współczynników demograficznych w ujęciu potencjalnym dynamicznym, obliczone dla Polski (2017 rok)

\begin{tabular}{|l|c|c|c|}
\hline \multirow{2}{*}{ Współczynniki potencjalne - ujęcie dynamiczne } & \multicolumn{3}{c|}{ Wartość współczynnika } \\
\cline { 2 - 4 } & Mężczyźni & Kobiety & Ogółem \\
\hline Starości demograficznej & 33,28 & 43,08 & 38,17 \\
\hline Zaawansowanej starości & 4,61 & 8,84 & 6,84 \\
\hline Podwójnego starzenia & 13,83 & 20,53 & 17,91 \\
\hline Indeks starości demograficznej & 1032 & 1627 & 1323 \\
\hline Współczynnik potencjalnego wsparcia & 88,86 & 128,58 & 104,58 \\
\hline
\end{tabular}

Źródło: opracowanie własne na podstawie TTŻ na rok 2017 (załącznik 2)

Współczynnik zaawansowanej starości w ujęciu dynamicznym dla ludności Polski w roku 2017 (bez podziału na płeć) wynosił 6,84\% (Tabela 7). Oznacza to, że liczba lat do przeżycia w okresie późnej starości przez osoby z całej populacji stanowiła prawie $7 \%$ całkowitego potencjału życiowego ludności. W przypadku mężczyzn współczynnik zaawansowanej starości w ujęciu dynamicznym wynosił w roku 2017 około 4,61\% i - podobnie jak w przypadku współczynnika starości demograficznej - był niższy od wskaźnika dla kobiet, równego 8,84\%.

\section{Podsumowanie}

Ujęcie tradycyjne starzenia odzwierciedla tylko zmiany w strukturze ludności według wieku, nie bierze natomiast pod uwagę zmian wynikających z wydłużania się czasu życia. Jednak zjawisko starzenia ma w istocie dwa wymiary, wyrażające się zarówno w zmianach w strukturze ludności według wieku, jak i w zmianach w średnim dalszym trwaniu życia. Innymi słowy, ważne jest tu nie tylko to, jaki odsetek osób osiągnął już określony wiek, lecz także to, ile średnio lat mogą one jeszcze żyć po osiągnięciu danego wieku. Ujęcie tego zagadnienia z perspektywy obu wymiarów jest możliwe jedynie z wykorzystaniem demografii potencjalnej, która uwzględnia oczekiwany czas dalszego życia jednostek. Ludność, która „ma więcej przyszłości”, może być w tym sensie traktowana jako populacja bogatsza.

Ujęcie potencjalne procesu starzenia się ludności stanowi cenne poznawczo uzupełnienie tradycyjnie stosowanych metod, ponieważ może uwzględniać na przykład potencjał życiowy osób aktualnie uznawanych za starsze, lecz również oczekiwaną liczbę lat, jaką mają do przeżycia w okresie starości osoby, które aktualnie nie osiągnęły jeszcze progu starości. Wskaźniki potencjalne w ujęciu statycznym można wykorzystać między innymi do planowania bieżących wydatków na programy społeczne i pomocowe dedykowane seniorom, natomiast mierniki w ujęciu dynamicznym mogą znaleźć zastosowanie na przykład do długofalowego planowania wydatków w ramach polityki ludnościowej państwa. 
Wskaźniki potencjalne nie są alternatywą wobec wskaźników tradycyjnych, lecz ich dopełnieniem. Pozwalają na bardziej kompleksowe określanie zaawansowania badanego zjawiska, w tym przypadku starzenia demograficznego. Metody demografii potencjalnej odnieść można jednak do różnych zjawisk demograficznych, takich jak rodność, umieralność, migracje. Ich stosowanie wymaga jednak wielu obliczeń opartych na danych z tablic trwania życia, dlatego bardziej popularne i częściej stosowane są nadal mierniki tradycyjne. Wartości miar w ujęciu potencjalnym dla ludności Polski stanowią ilustrację zastosowania tych miar do opisu procesu starzenia się ludności. Analiza tempa zmian tych współczynników w Polsce oraz prognozy ich poziomu w przyszłości będą celem badań autora w kolejnej pracy.

\section{Bibliografia}

Blangiardo G.C., Rimoldi S. M.L. (2013), The potential demography: a tool for evaluating differences among countries in the European Union, „Genus”, t. LXVIII, nr 3, s. 63-81.

Bongaarts J. (2006), How long do we live?, „Population Development Review”, nr 32, s. 605-626. Carnes B., Olshansky S.J. (2007), A realistic view of aging, mortality and future longevity, „Population Development Review", nr 33, s. 367-381.

Fries J. (1980), Aging, natural death, and the compression or morbidity, „New England Journal of Medicine", nr 303, s. 130-135.

Kędelski M., Paradysz J. (2006), Demografia, Wydawnictwo Akademii Ekonomicznej w Poznaniu, Poznań.

Lutz W., Sanderson W., Scherbov S. (2008), The coming acceleration of global population ageing, „Nature”, nr 451, s. 716-719.

Manton K., Stallard E., Trolley H. (1991), Limits to human life expectancy: evidence, prospects and implications, „Population Development Review”, nr 17, s. 603-637.

Murkowski R. (2013), Potencjal życiowy ludności państw Unii Europejskiej w latach 1995-2009, rozprawa doktorska, Uniwersytet Ekonomiczny w Poznaniu, Wydział Ekonomii, Katedra Statystyki i Demografii, Poznań.

Murkowski R. (2018a), Metody pomiaru zaawansowania procesu starzenia się ludności, „Humanities and Social Sciences", t. XXIII, nr 25(3), s. 213-229.

Murkowski R. (2018b), Zaawansowanie procesu starzenia się populacji Polski w latach 1990-2050, „Studia Oeconomica Posnaniensia”, nr 6(9), s. 59-77.

Oeppen J., Vaupel J. (2002), Broken limits to life expectancy, „Science”, nr 296, s. 1029-1031.

Panush N., Peritz E. (1996), Potential demography. A second look, „European Journal of Population", nr 12, s. 27-39.

Sanderson W., Scherbov S. (2005), Average remaining lifetimes can increase as human populations age, ,Nature”, nr 435, s. 811-813.

Sanderson W., Scherbov S. (2006), A new perspective on population aging, „Demographic Research", nr 16, s. 27-58.

Vielrose E. (1958), Zarys demografii potencjalnej, Państwowe Wydawnictwo Naukowe, Warszawa. 


\section{Załączniki}

Załącznik 1. Podstawowe charakterystyki demograficzne ludności Polski w roku 2010 oraz w latach 2016-2018

\begin{tabular}{|c|c|c|c|c|c|c|c|c|c|}
\hline \multirow{3}{*}{\multicolumn{2}{|c|}{$\begin{array}{c}\text { Liczba ludności } \\
\text { (wg stanu na } 31 \text { XII) }\end{array}$}} & \multicolumn{8}{|c|}{ Lata } \\
\hline & & \multicolumn{2}{|c|}{2010} & \multicolumn{2}{|c|}{2016} & \multicolumn{2}{|c|}{2017} & \multicolumn{2}{|c|}{2018} \\
\hline & & \multicolumn{2}{|c|}{38022869} & \multicolumn{2}{|c|}{37967209} & \multicolumn{2}{|c|}{37972964} & \multicolumn{2}{|c|}{37976687} \\
\hline Kobiety & Mężczyźni & 19610632 & 18412237 & 19590169 & 18377040 & 18377837 & 19595127 & 19596388 & 18380299 \\
\hline \multicolumn{2}{|l|}{ Liczba urodzeń } & \multicolumn{2}{|c|}{413300} & \multicolumn{2}{|c|}{382257} & \multicolumn{2}{|c|}{401982} & \multicolumn{2}{|c|}{ brak danych } \\
\hline \multicolumn{2}{|l|}{ Liczba zgonów ogółem } & \multicolumn{2}{|c|}{378478} & \multicolumn{2}{|c|}{388009} & \multicolumn{2}{|c|}{402852} & \multicolumn{2}{|c|}{ brak danych } \\
\hline \multicolumn{2}{|c|}{ Liczba zgonów niemowląt } & \multicolumn{2}{|c|}{2057} & \multicolumn{2}{|c|}{1522} & \multicolumn{2}{|c|}{1604} & \multicolumn{2}{|c|}{ brak danych } \\
\hline \multicolumn{2}{|c|}{ Saldo migracji zewnętrznych } & \multicolumn{2}{|c|}{-62995} & \multicolumn{2}{|c|}{-28139} & \multicolumn{2}{|c|}{-9139} & \multicolumn{2}{|c|}{ brak danych } \\
\hline \multicolumn{2}{|c|}{$\begin{array}{l}\text { Udział ludności } 65+\text { (w proc.) } \\
W_{65+}\end{array}$} & \multicolumn{2}{|c|}{13,6} & \multicolumn{2}{|c|}{16,0} & \multicolumn{2}{|c|}{16,5} & \multicolumn{2}{|c|}{17,1} \\
\hline Kobiety & Mężczyźni & 3231029 & 1946489 & 3699049 & 2360428 & 3821811 & 2461840 & 3936492 & 2560868 \\
\hline $\begin{array}{l}\text { Procentowa wartość } \\
\text { kobiet } 65+\text { w stosunku } \\
\text { do wszystkich kobiet }\end{array}$ & $\begin{array}{l}\text { Procentowa wartość } \\
\text { mężczyzn } 65+\text { w sto- } \\
\text { sunku do wszystkich } \\
\text { mężczyzn }\end{array}$ & 16,47 & 10,58 & 18,82 & 12,84 & 20,79 & 12,56 & 20,09 & 13,93 \\
\hline $\begin{array}{l}\text { Procentowa wartość } \\
\text { kobiet } 85+\text { w stosunku } \\
\text { do wszystkich kobiet }\end{array}$ & $\begin{array}{l}\text { Procentowa wartość } \\
\text { mężczyzn } 85+\text { w sto- } \\
\text { sunku do wszystkich } \\
\text { mężczyzn }\end{array}$ & 1,81 & 0,67 & 2,6 & 1,04 & 2,73 & 1,11 & 2,83 & 1,59 \\
\hline \multicolumn{2}{|l|}{ Mediana wieku } & \multicolumn{2}{|c|}{37,9} & \multicolumn{2}{|c|}{39,9} & & 0,3 & 40 & 6 \\
\hline
\end{tabular}

Źródło: opracowanie własne na podstawie danych Eurostatu 
Załącznik 2. Tablica trwania życia 2017 r.

\begin{tabular}{|c|c|c|c|c|c|c|c|}
\hline $\begin{array}{c}\text { Pleć: } \\
1 \text { - mężcz. } \\
2 \text { - kobiety }\end{array}$ & Wiek & $\begin{array}{c}\text { Liczba } \\
\text { dożywa- } \\
\text { jących }\end{array}$ & $\begin{array}{c}\text { Prawdopo- } \\
\text { dobieństwo } \\
\text { zgonu }\end{array}$ & $\begin{array}{l}\text { Liczba } \\
\text { zmar- } \\
\text { lych }\end{array}$ & $\begin{array}{l}\text { Ludność } \\
\text { stacjo- } \\
\text { narna }\end{array}$ & $\begin{array}{c}\text { Ludność } \\
\text { stacjonarna } \\
\text { skumulowana }\end{array}$ & $\begin{array}{l}\text { Przecięt- } \\
\text { ne dalsze } \\
\text { trwanie } \\
\text { życia }\end{array}$ \\
\hline & $\mathbf{X}$ & IX & $q x$ & $d x$ & LX & $\mathbf{T x}$ & ex \\
\hline 1 & 0 & 100000 & 0,00446 & 446 & 99611 & 7396267 & 73,96 \\
\hline 1 & 1 & 99554 & 0,00028 & 28 & 99540 & 7296656 & 73,29 \\
\hline 1 & 2 & 99526 & 0,00019 & 19 & 99516 & 7197117 & 72,31 \\
\hline 1 & 3 & 99506 & 0,00013 & 13 & 99500 & 7097601 & 71,33 \\
\hline 1 & 4 & 99493 & 0,00010 & 10 & 99488 & 6998101 & 70,34 \\
\hline 1 & 5 & 99482 & 0,00009 & 9 & 99478 & 6898614 & 69,35 \\
\hline 1 & 6 & 99473 & 0,00009 & 9 & 99469 & 6799136 & 68,35 \\
\hline 1 & 7 & 99464 & 0,00009 & 9 & 99460 & 6699667 & 67,36 \\
\hline 1 & 8 & 99455 & 0,00009 & 9 & 99450 & 6600207 & 66,36 \\
\hline 1 & 9 & 99446 & 0,00009 & 9 & 99441 & 6500757 & 65,37 \\
\hline 1 & 10 & 99436 & 0,00010 & 10 & 99432 & 6401316 & 64,38 \\
\hline 1 & 11 & 99427 & 0,00010 & 10 & 99422 & 6301884 & 63,38 \\
\hline 1 & 12 & 99417 & 0,00011 & 11 & 99411 & 6202462 & 62,39 \\
\hline 1 & 13 & 99405 & 0,00013 & 13 & 99399 & 6103051 & 61,40 \\
\hline 1 & 14 & 99392 & 0,00017 & 16 & 99384 & 6003653 & 60,40 \\
\hline 1 & 15 & 99376 & 0,00022 & 22 & 99365 & 5904268 & 59,41 \\
\hline 1 & 16 & 99354 & 0,00032 & 32 & 99338 & 5804904 & 58,43 \\
\hline 1 & 17 & 99322 & 0,00045 & 45 & 99299 & 5705566 & 57,45 \\
\hline 1 & 18 & 99277 & 0,00059 & 58 & 99248 & 5606267 & 56,47 \\
\hline 1 & 19 & 99219 & 0,00071 & 71 & 99183 & 5507019 & 55,50 \\
\hline 1 & 20 & 99148 & 0,00080 & 79 & 99108 & 5407835 & 54,54 \\
\hline 1 & 21 & 99069 & 0,00085 & 84 & 99027 & 5308727 & 53,59 \\
\hline 1 & 22 & 98985 & 0,00088 & 87 & 98941 & 5209700 & 52,63 \\
\hline 1 & 23 & 98898 & 0,00090 & 89 & 98853 & 5110759 & 51,68 \\
\hline 1 & 24 & 98809 & 0,00093 & 92 & 98763 & 5011906 & 50,72 \\
\hline 1 & 25 & 98716 & 0,00097 & 96 & 98668 & 4913143 & 49,77 \\
\hline 1 & 26 & 98621 & 0,00101 & 100 & 98571 & 4814475 & 48,82 \\
\hline 1 & 27 & 98521 & 0,00105 & 103 & 98469 & 4715904 & 47,87 \\
\hline 1 & 28 & 98417 & 0,00109 & 107 & 98364 & 4617435 & 46,92 \\
\hline 1 & 29 & 98310 & 0,00114 & 113 & 98254 & 4519071 & 45,97 \\
\hline 1 & 30 & 98197 & 0,00121 & 119 & 98138 & 4420817 & 45,02 \\
\hline 1 & 31 & 98079 & 0,00128 & 126 & 98016 & 4322679 & 44,07 \\
\hline 1 & 32 & 97953 & 0,00136 & 133 & 97887 & 4224663 & 43,13 \\
\hline 1 & 33 & 97820 & 0,00145 & 142 & 97749 & 4126777 & 42,19 \\
\hline 1 & 34 & 97679 & 0,00154 & 151 & 97603 & 4029027 & 41,25 \\
\hline 1 & 35 & 97528 & 0,00165 & 161 & 97447 & 3931424 & 40,31 \\
\hline 1 & 36 & 97367 & 0,00177 & 172 & 97281 & 3833977 & 39,38 \\
\hline 1 & 37 & 97195 & 0,00191 & 185 & 97102 & 3736696 & 38,45 \\
\hline 1 & 38 & 97009 & 0,00207 & 200 & 96909 & 3639594 & 37,52 \\
\hline
\end{tabular}




\begin{tabular}{|c|c|c|c|c|c|c|c|}
\hline $\begin{array}{c}\text { Pleć: } \\
1 \text { - mężcz. } \\
\text { 2- kobiety }\end{array}$ & Wiek & $\begin{array}{l}\text { Liczba } \\
\text { dożywa- } \\
\text { jących }\end{array}$ & $\begin{array}{c}\text { Prawdopo- } \\
\text { dobieństwo } \\
\text { zgonu }\end{array}$ & $\begin{array}{c}\text { Liczba } \\
\text { zmar- } \\
\text { lych }\end{array}$ & $\begin{array}{c}\text { Ludność } \\
\text { stacjo- } \\
\text { narna }\end{array}$ & $\begin{array}{c}\text { Ludność } \\
\text { stacjonarna } \\
\text { skumulowana }\end{array}$ & $\begin{array}{c}\text { Przecięt- } \\
\text { ne dalsze } \\
\text { trwanie } \\
\text { życia } \\
\end{array}$ \\
\hline & $\mathbf{X}$ & Ix & $q x$ & $d x$ & LX & $\mathbf{T x}$ & ex \\
\hline 1 & 39 & 96809 & 0,00225 & 218 & 96700 & 3542684 & 36,59 \\
\hline 1 & 40 & 96591 & 0,00246 & 238 & 96473 & 3445984 & 35,68 \\
\hline 1 & 41 & 96354 & 0,00270 & 261 & 96223 & 3349512 & 34,76 \\
\hline 1 & 42 & 96093 & 0,00298 & 286 & 95950 & 3253288 & 33,86 \\
\hline 1 & 43 & 95807 & 0,00329 & 315 & 95649 & 3157338 & 32,96 \\
\hline 1 & 44 & 95491 & 0,00364 & 347 & 95318 & 3061689 & 32,06 \\
\hline 1 & 45 & 95144 & 0,00402 & 382 & 94953 & 2966372 & 31,18 \\
\hline 1 & 46 & 94761 & 0,00444 & 421 & 94551 & 2871419 & 30,30 \\
\hline 1 & 47 & 94341 & 0,00490 & 462 & 94109 & 2776868 & 29,43 \\
\hline 1 & 48 & 93878 & 0,00541 & 508 & 93624 & 2682758 & 28,58 \\
\hline 1 & 49 & 93371 & 0,00596 & 557 & 93092 & 2589134 & 27,73 \\
\hline 1 & 50 & 92814 & 0,00657 & 610 & 92509 & 2496041 & 26,89 \\
\hline 1 & 51 & 92205 & 0,00724 & 667 & 91871 & 2403532 & 26,07 \\
\hline 1 & 52 & 91537 & 0,00797 & 730 & 91173 & 2311661 & 25,25 \\
\hline 1 & 53 & 90808 & 0,00877 & 796 & 90410 & 2220489 & 24,45 \\
\hline 1 & 54 & 90011 & 0,00964 & 868 & 89577 & 2130079 & 23,66 \\
\hline 1 & 55 & 89143 & 0,01059 & 944 & 88671 & 2040502 & 22,89 \\
\hline 1 & 56 & 88199 & 0,01161 & 1024 & 87688 & 1951830 & 22,13 \\
\hline 1 & 57 & 87176 & 0,01270 & 1107 & 86622 & 1864143 & 21,38 \\
\hline 1 & 58 & 86069 & 0,01386 & 1193 & 85472 & 1777521 & 20,65 \\
\hline 1 & 59 & 84876 & 0,01509 & 1281 & 84235 & 1692049 & 19,94 \\
\hline 1 & 60 & 83594 & 0,01640 & 1371 & 82909 & 1607813 & 19,23 \\
\hline 1 & 61 & 82224 & 0,01778 & 1462 & 81493 & 1524904 & 18,55 \\
\hline 1 & 62 & 80762 & 0,01922 & 1552 & 79986 & 1443412 & 17,87 \\
\hline 1 & 63 & 79210 & 0,02073 & 1642 & 78389 & 1363426 & 17,21 \\
\hline 1 & 64 & 77568 & 0,02231 & 1730 & 76703 & 1285037 & 16,57 \\
\hline 1 & 65 & 75837 & 0,02394 & 1816 & 74929 & 1208334 & 15,93 \\
\hline 1 & 66 & 74022 & 0,02565 & 1898 & 73072 & 1133405 & 15,31 \\
\hline 1 & 67 & 72123 & 0,02741 & 1977 & 71135 & 1060333 & 14,70 \\
\hline 1 & 68 & 70146 & 0,02926 & 2052 & 69120 & 989198 & 14,10 \\
\hline 1 & 69 & 68094 & 0,03121 & 2125 & 67031 & 920078 & 13,51 \\
\hline 1 & 70 & 65969 & 0,03329 & 2196 & 64871 & 853047 & 12,93 \\
\hline 1 & 71 & 63773 & 0,03555 & 2267 & 62639 & 788176 & 12,36 \\
\hline 1 & 72 & 61506 & 0,03806 & 2341 & 60335 & 725537 & 11,80 \\
\hline 1 & 73 & 59165 & 0,04086 & 2418 & 57956 & 665201 & 11,24 \\
\hline 1 & 74 & 56747 & 0,04404 & 2499 & 55498 & 607245 & 10,70 \\
\hline 1 & 75 & 54248 & 0,04765 & 2585 & 52956 & 551748 & 10,17 \\
\hline 1 & 76 & 51663 & 0,05174 & 2673 & 50326 & 498792 & 9,65 \\
\hline 1 & 77 & 48990 & 0,05635 & 2760 & 47610 & 448466 & 9,15 \\
\hline 1 & 78 & 46229 & 0,06148 & 2842 & 44808 & 400856 & 8,67 \\
\hline
\end{tabular}




\begin{tabular}{|c|c|c|c|c|c|c|c|}
\hline \multirow[t]{2}{*}{$\begin{array}{c}\text { Pleć: } \\
1 \text { - mężcz. } \\
2 \text { - kobiety }\end{array}$} & Wiek & $\begin{array}{c}\text { Liczba } \\
\text { dożywa- } \\
\text { jących }\end{array}$ & $\begin{array}{c}\text { Prawdopo- } \\
\text { dobieństwo } \\
\text { zgonu }\end{array}$ & $\begin{array}{l}\text { Liczba } \\
\text { zmar- } \\
\text { lych }\end{array}$ & $\begin{array}{c}\text { Ludność } \\
\text { stacjo- } \\
\text { narna }\end{array}$ & $\begin{array}{c}\text { Ludność } \\
\text { stacjonarna } \\
\text { skumulowana }\end{array}$ & $\begin{array}{l}\text { Przecięt- } \\
\text { ne dalsze } \\
\text { trwanie } \\
\text { życia }\end{array}$ \\
\hline & $\mathbf{X}$ & Ix & $q x$ & $d x$ & LX & $\mathbf{T x}$ & ex \\
\hline 1 & 79 & 43387 & 0,06715 & 2913 & 41930 & 356048 & 8,21 \\
\hline 1 & 80 & 40474 & 0,07332 & 2968 & 38990 & 314117 & 7,76 \\
\hline 1 & 81 & 37506 & 0,07999 & 3000 & 36006 & 275127 & 7,34 \\
\hline 1 & 82 & 34506 & 0,08713 & 3007 & 33003 & 239121 & 6,93 \\
\hline 1 & 83 & 31499 & 0,09474 & 2984 & 30007 & 206119 & 6,54 \\
\hline 1 & 84 & 28515 & 0,10280 & 2931 & 27049 & 176111 & 6,18 \\
\hline 1 & 85 & 25584 & 0,11135 & 2849 & 24159 & 149062 & 5,83 \\
\hline 1 & 86 & 22735 & 0,12041 & 2738 & 21366 & 124903 & 5,49 \\
\hline 1 & 87 & 19998 & 0,13001 & 2600 & 18698 & 103536 & 5,18 \\
\hline 1 & 88 & 17398 & 0,14024 & 2440 & 16178 & 84839 & 4,88 \\
\hline 1 & 89 & 14958 & 0,15116 & 2261 & 13827 & 68661 & 4,59 \\
\hline 1 & 90 & 12697 & 0,16272 & 2066 & 11664 & 54834 & 4,32 \\
\hline 1 & 91 & 10631 & 0,17525 & 1863 & 9699 & 43170 & 4,06 \\
\hline 1 & 92 & 8768 & 0,18851 & 1653 & 7941 & 33471 & 3,82 \\
\hline 1 & 93 & 7115 & 0,20250 & 1441 & 6395 & 25530 & 3,59 \\
\hline 1 & 94 & 5674 & 0,21722 & 1233 & 5058 & 19135 & 3,37 \\
\hline 1 & 95 & 4442 & 0,23268 & 1033 & 3925 & 14077 & 3,17 \\
\hline 1 & 96 & 3408 & 0,24886 & 848 & 2984 & 10152 & 2,98 \\
\hline 1 & 97 & 2560 & 0,26575 & 680 & 2220 & 7168 & 2,80 \\
\hline 1 & 98 & 1880 & 0,28334 & 533 & 1613 & 4948 & 2,63 \\
\hline 1 & 99 & 1347 & 0,30162 & 406 & 1144 & 3335 & 2,48 \\
\hline 1 & 100 & 941 & 0,32054 & 302 & 790 & 2191 & 2,33 \\
\hline 2 & 0 & 100000 & 0,00361 & 361 & 99685 & 8181635 & 81,82 \\
\hline 2 & 1 & 99639 & 0,00023 & 23 & 99627 & 8081950 & 81,11 \\
\hline 2 & 2 & 99616 & 0,00015 & 15 & 99608 & 7982322 & 80,13 \\
\hline 2 & 3 & 99601 & 0,00010 & 10 & 99596 & 7882714 & 79,14 \\
\hline 2 & 4 & 99591 & 0,00008 & 8 & 99587 & 7783118 & 78,15 \\
\hline 2 & 5 & 99583 & 0,00008 & 8 & 99579 & 7683531 & 77,16 \\
\hline 2 & 6 & 99575 & 0,00008 & 8 & 99571 & 7583952 & 76,16 \\
\hline 2 & 7 & 99567 & 0,00008 & 7 & 99563 & 7484381 & 75,17 \\
\hline 2 & 8 & 99559 & 0,00007 & 7 & 99556 & 7384818 & 74,17 \\
\hline 2 & 9 & 99553 & 0,00007 & 7 & 99549 & 7285262 & 73,18 \\
\hline 2 & 10 & 99546 & 0,00007 & 7 & 99542 & 7185713 & 72,18 \\
\hline 2 & 11 & 99539 & 0,00008 & 8 & 99535 & 7086170 & 71,19 \\
\hline 2 & 12 & 99531 & 0,00010 & 10 & 99526 & 6986636 & 70,20 \\
\hline 2 & 13 & 99521 & 0,00012 & 12 & 99515 & 6887110 & 69,20 \\
\hline 2 & 14 & 99509 & 0,00014 & 14 & 99502 & 6787595 & 68,21 \\
\hline 2 & 15 & 99495 & 0,00016 & 16 & 99487 & 6688093 & 67,22 \\
\hline 2 & 16 & 99479 & 0,00019 & 19 & 99469 & 6588606 & 66,23 \\
\hline 2 & 17 & 99460 & 0,00022 & 22 & 99449 & 6489137 & 65,24 \\
\hline
\end{tabular}




\begin{tabular}{|c|c|c|c|c|c|c|c|}
\hline $\begin{array}{c}\text { Pleć: } \\
1 \text { - mężcz. } \\
2-\text { kobiety }\end{array}$ & Wiek & $\begin{array}{l}\text { Liczba } \\
\text { dożywa- } \\
\text { jących }\end{array}$ & $\begin{array}{c}\text { Prawdopo- } \\
\text { dobieństwo } \\
\text { zgonu }\end{array}$ & $\begin{array}{c}\text { Liczba } \\
\text { zmar- } \\
\text { lych }\end{array}$ & $\begin{array}{c}\text { Ludność } \\
\text { stacjo- } \\
\text { narna }\end{array}$ & $\begin{array}{c}\text { Ludność } \\
\text { stacjonarna } \\
\text { skumulowana }\end{array}$ & $\begin{array}{l}\text { Przecięt- } \\
\text { ne dalsze } \\
\text { trwanie } \\
\text { życia }\end{array}$ \\
\hline & $\mathbf{X}$ & $\mathbf{l x}$ & $q x$ & $d x$ & $\mathbf{L X}$ & $\mathbf{T x}$ & ex \\
\hline 2 & 18 & 99438 & 0,00024 & 24 & 99426 & 6389688 & 64,26 \\
\hline 2 & 19 & 99414 & 0,00026 & 25 & 99401 & 6290262 & 63,27 \\
\hline 2 & 20 & 99389 & 0,00026 & 25 & 99376 & 6190861 & 62,29 \\
\hline 2 & 21 & 99363 & 0,00025 & 25 & 99351 & 6091485 & 61,31 \\
\hline 2 & 22 & 99339 & 0,00024 & 24 & 99327 & 5992134 & 60,32 \\
\hline 2 & 23 & 99315 & 0,00023 & 23 & 99304 & 5892808 & 59,33 \\
\hline 2 & 24 & 99292 & 0,00023 & 23 & 99281 & 5793504 & 58,35 \\
\hline 2 & 25 & 99269 & 0,00023 & 23 & 99258 & 5694223 & 57,36 \\
\hline 2 & 26 & 99246 & 0,00025 & 24 & 99234 & 5594965 & 56,37 \\
\hline 2 & 27 & 99222 & 0,00026 & 26 & 99209 & 5495731 & 55,39 \\
\hline 2 & 28 & 99196 & 0,00028 & 28 & 99182 & 5396523 & 54,40 \\
\hline 2 & 29 & 99168 & 0,00031 & 31 & 99152 & 5297341 & 53,42 \\
\hline 2 & 30 & 99137 & 0,00033 & 33 & 99121 & 5198189 & 52,43 \\
\hline 2 & 31 & 99104 & 0,00035 & 35 & 99087 & 5099068 & 51,45 \\
\hline 2 & 32 & 99069 & 0,00038 & 38 & 99050 & 4999981 & 50,47 \\
\hline 2 & 33 & 99031 & 0,00041 & 41 & 99011 & 4900930 & 49,49 \\
\hline 2 & 34 & 98990 & 0,00045 & 45 & 98968 & 4801919 & 48,51 \\
\hline 2 & 35 & 98946 & 0,00050 & 49 & 98921 & 4702951 & 47,53 \\
\hline 2 & 36 & 98897 & 0,00055 & 54 & 98870 & 4604030 & 46,55 \\
\hline 2 & 37 & 98843 & 0,00060 & 60 & 98813 & 4505160 & 45,58 \\
\hline 2 & 38 & 98783 & 0,00067 & 66 & 98750 & 4406348 & 44,61 \\
\hline 2 & 39 & 98717 & 0,00075 & 74 & 98680 & 4307598 & 43,64 \\
\hline 2 & 40 & 98643 & 0,00084 & 83 & 98601 & 4208918 & 42,67 \\
\hline 2 & 41 & 98560 & 0,00094 & 92 & 98514 & 4110317 & 41,70 \\
\hline 2 & 42 & 98467 & 0,00105 & 103 & 98416 & 4011803 & 40,74 \\
\hline 2 & 43 & 98364 & 0,00118 & 116 & 98306 & 3913388 & 39,78 \\
\hline 2 & 44 & 98248 & 0,00131 & 129 & 98184 & 3815082 & 38,83 \\
\hline 2 & 45 & 98119 & 0,00146 & 144 & 98047 & 3716898 & 37,88 \\
\hline 2 & 46 & 97976 & 0,00163 & 160 & 97896 & 3618850 & 36,94 \\
\hline 2 & 47 & 97816 & 0,00181 & 177 & 97728 & 3520955 & 36,00 \\
\hline 2 & 48 & 97639 & 0,00200 & 196 & 97542 & 3423227 & 35,06 \\
\hline 2 & 49 & 97444 & 0,00222 & 216 & 97336 & 3325685 & 34,13 \\
\hline 2 & 50 & 97227 & 0,00246 & 239 & 97108 & 3228350 & 33,20 \\
\hline 2 & 51 & 96989 & 0,00272 & 264 & 96857 & 3131242 & 32,28 \\
\hline 2 & 52 & 96725 & 0,00301 & 291 & 96579 & 3034385 & 31,37 \\
\hline 2 & 53 & 96433 & 0,00334 & 322 & 96272 & 2937806 & 30,46 \\
\hline 2 & 54 & 96111 & 0,00370 & 355 & 95934 & 2841534 & 29,57 \\
\hline 2 & 55 & 95756 & 0,00409 & 392 & 95560 & 2745601 & 28,67 \\
\hline 2 & 56 & 95364 & 0,00452 & 431 & 95149 & 2650040 & 27,79 \\
\hline 2 & 57 & 94933 & 0,00499 & 474 & 94697 & 2554891 & 26,91 \\
\hline
\end{tabular}




\begin{tabular}{|c|c|c|c|c|c|c|c|}
\hline \multirow[t]{2}{*}{$\begin{array}{c}\text { Pleć: } \\
\text { 1- mężcz. } \\
\text { 2- kobiety }\end{array}$} & Wiek & $\begin{array}{c}\text { Liczba } \\
\text { dożywa- } \\
\text { jących }\end{array}$ & $\begin{array}{c}\text { Prawdopo- } \\
\text { dobieństwo } \\
\text { zgonu }\end{array}$ & $\begin{array}{l}\text { Liczba } \\
\text { zmar- } \\
\text { lych }\end{array}$ & $\begin{array}{c}\text { Ludność } \\
\text { stacjo- } \\
\text { narna }\end{array}$ & $\begin{array}{c}\text { Ludność } \\
\text { stacjonarna } \\
\text { skumulowana }\end{array}$ & $\begin{array}{l}\text { Przecięt- } \\
\text { ne dalsze } \\
\text { trwanie } \\
\text { życia }\end{array}$ \\
\hline & $\mathbf{X}$ & Ix & $q x$ & $d x$ & LX & $\mathbf{T x}$ & ex \\
\hline 2 & 58 & 94460 & 0,00550 & 519 & 94200 & 2460195 & 26,04 \\
\hline 2 & 59 & 93941 & 0,00605 & 568 & 93656 & 2365994 & 25,19 \\
\hline 2 & 60 & 93372 & 0,00665 & 621 & 93062 & 2272338 & 24,34 \\
\hline 2 & 61 & 92751 & 0,00730 & 677 & 92412 & 2179277 & 23,50 \\
\hline 2 & 62 & 92074 & 0,00801 & 737 & 91705 & 2086864 & 22,67 \\
\hline 2 & 63 & 91336 & 0,00877 & 801 & 90936 & 1995159 & 21,84 \\
\hline 2 & 64 & 90535 & 0,00960 & 869 & 90101 & 1904223 & 21,03 \\
\hline 2 & 65 & 89667 & 0,01048 & 940 & 89197 & 1814122 & 20,23 \\
\hline 2 & 66 & 88727 & 0,01143 & 1014 & 88220 & 1724926 & 19,44 \\
\hline 2 & 67 & 87713 & 0,01243 & 1090 & 87168 & 1636706 & 18,66 \\
\hline 2 & 68 & 86623 & 0,01350 & 1169 & 86038 & 1549538 & 17,89 \\
\hline 2 & 69 & 85453 & 0,01463 & 1250 & 84828 & 1463500 & 17,13 \\
\hline 2 & 70 & 84203 & 0,01585 & 1335 & 83536 & 1378672 & 16,37 \\
\hline 2 & 71 & 82869 & 0,01718 & 1424 & 82157 & 1295136 & 15,63 \\
\hline 2 & 72 & 81445 & 0,01866 & 1520 & 80685 & 1212979 & 14,89 \\
\hline 2 & 73 & 79925 & 0,02035 & 1627 & 79112 & 1132294 & 14,17 \\
\hline 2 & 74 & 78299 & 0,02232 & 1748 & 77425 & 1053182 & 13,45 \\
\hline 2 & 75 & 76551 & 0,02464 & 1887 & 75608 & 975757 & 12,75 \\
\hline 2 & 76 & 74665 & 0,02741 & 2046 & 73641 & 900149 & 12,06 \\
\hline 2 & 77 & 72618 & 0,03068 & 2228 & 71504 & 826508 & 11,38 \\
\hline 2 & 78 & 70390 & 0,03454 & 2431 & 69175 & 755004 & 10,73 \\
\hline 2 & 79 & 67959 & 0,03903 & 2653 & 66633 & 685829 & 10,09 \\
\hline 2 & 80 & 65306 & 0,04420 & 2886 & 63863 & 619196 & 9,48 \\
\hline 2 & 81 & 62420 & 0,05005 & 3124 & 60858 & 555333 & 8,90 \\
\hline 2 & 82 & 59296 & 0,05659 & 3355 & 57619 & 494475 & 8,34 \\
\hline 2 & 83 & 55941 & 0,06381 & 3570 & 54156 & 436856 & 7,81 \\
\hline 2 & 84 & 52371 & 0,07171 & 3756 & 50493 & 382700 & 7,31 \\
\hline 2 & 85 & 48615 & 0,08029 & 3903 & 46664 & 332207 & 6,83 \\
\hline 2 & 86 & 44712 & 0,08955 & 4004 & 42710 & 285544 & 6,39 \\
\hline 2 & 87 & 40708 & 0,09949 & 4050 & 38683 & 242833 & 5,97 \\
\hline 2 & 88 & 36658 & 0,11018 & 4039 & 34639 & 204150 & 5,57 \\
\hline 2 & 89 & 32619 & 0,12164 & 3968 & 30635 & 169512 & 5,20 \\
\hline 2 & 90 & 28651 & 0,13389 & 3836 & 26733 & 138876 & 4,85 \\
\hline 2 & 91 & 24815 & 0,14710 & 3650 & 22990 & 112143 & 4,52 \\
\hline 2 & 92 & 21165 & 0,16120 & 3412 & 19459 & 89153 & 4,21 \\
\hline 2 & 93 & 17753 & 0,17620 & 3128 & 16189 & 69694 & 3,93 \\
\hline 2 & 94 & 14625 & 0,19212 & 2810 & 13220 & 53505 & 3,66 \\
\hline 2 & 95 & 11815 & 0,20894 & 2469 & 10581 & 40285 & 3,41 \\
\hline 2 & 96 & 9347 & 0,22666 & 2118 & 8287 & 29704 & 3,18 \\
\hline 2 & 97 & 7228 & 0,24526 & 1773 & 6342 & 21417 & 2,96 \\
\hline
\end{tabular}




\begin{tabular}{|c|c|c|c|c|c|c|c|}
\hline $\begin{array}{c}\text { Pleć: } \\
\text { 1 - mężcz. } \\
\text { 2- kobiety }\end{array}$ & Wiek & $\begin{array}{c}\text { Liczba } \\
\text { dożywa- } \\
\text { jących }\end{array}$ & $\begin{array}{c}\text { Prawdopo- } \\
\text { dobieństwo } \\
\text { zgonu }\end{array}$ & $\begin{array}{c}\text { Liczba } \\
\text { zmar- } \\
\text { lych }\end{array}$ & $\begin{array}{c}\text { Ludność } \\
\text { stacjo- } \\
\text { narna }\end{array}$ & $\begin{array}{c}\text { Ludność } \\
\text { stacjonarna } \\
\text { skumulowana }\end{array}$ & $\begin{array}{c}\text { Przecięt- } \\
\text { ne dalsze } \\
\text { trwanie } \\
\text { życia }\end{array}$ \\
\hline 2 & $\mathbf{X}$ & $\mathbf{q x}$ & $\mathbf{d x}$ & $\mathbf{L X}$ & $\mathbf{T x}$ & $\mathbf{\text { ex }}$ \\
\hline 2 & 98 & 5455 & 0,26473 & 1444 & 4733 & 15075 & 2,76 \\
\hline 2 & 99 & 4011 & 0,28504 & 1143 & 3439 & 10342 & 2,58 \\
\hline
\end{tabular}

\section{Measures of Population Ageing in Terms of the Potential Approach - Analysis Based on the Example of Poland}

Abstract: The article presents the proposals for population aging rates defined from the perspective of potential demography - in a static and dynamic perspective. It also presents the method of calculating life potentials for the population and for individual age groups, which are the starting point in potential demography. The values of the population aging rates in terms of the concepts of potential demography were calculated for Poland as a case study.

Keywords: demography, population ageing, potential demography

JEL: J11, J14

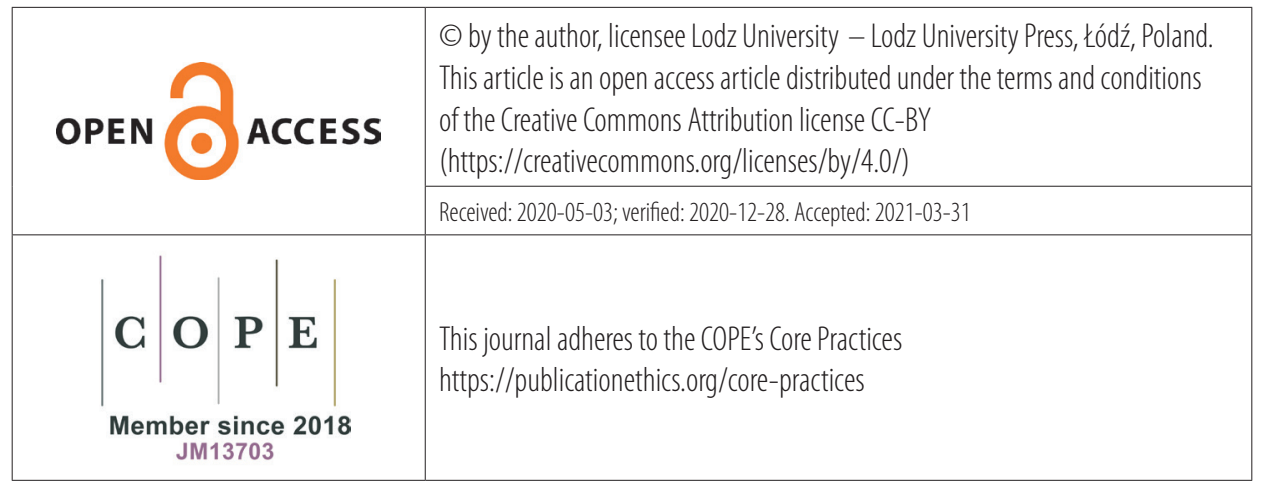

